SOUTHERN BRAZILIAN JOURNAL OF CHEMISTRY

SOUTH. BRAZ. J. CHEM., Vol. 21, No. 21, 2013

\title{
A TRIBUTE TO PROF. DR. LAVINEL G. IONESCU ON HIS $70^{\text {th }}$ BIRTHDAY
}

\author{
A.D. Martinez \\ Thunderbird Research Associates \\ Santa Fe, New Mexico USA \\ and \\ B. J. Kid \\ Pacific Consulting Services \\ Los Angeles, California USA
}

\begin{abstract}
Professor Dr. Lavinel G. Ionescu was born of Romanian parents in Várset (Vrsac, Werschetz), Banat, Yugoslavia (present day Serbia) on May 19, 1943. He attended primary and secondary schools in Yugoslavia, Italy and Switzerland. He did his undergraduate studies at Compton College, University of California at Los Angeles and the University of New Mexica. He obtained the B.S. Degree in Chemistry from the University of New Mexico, Albuquerque, USA in 1964 and the M.S. Degree in 1966. He was awarded the Ph.D. Degree in Physical Chemistry by New Mexico State University, Las Cruces, USA in 1970. He also attended Medical School. Prof. L. G. Ionescu is a U.S. citizen. He did postdoctoral work at the University of California, Santa Barbara and has held faculty positions at umiversities in the United States and Brazil. He was instrumental in the establishment of many graduate or undergraduate programs in chemistry, chemical engineering, pharmacy. materials science and engineering and science education in Brazil and the United States. His research work includes liquid scintillators, radioactive isotopes, noble gases, solution thermodynamics, surfactants and micelles, micellar catalysis, respiratory pigments, membrane models and history and philosophy of science. He has trained more than one hundred scientists from different parts of the world, is the author of approximately three hundred and fifty scientific works and has been the recipient of many prizes and awards.
\end{abstract}

\section{RESUMO}

Professor Dr. Lavinel G. Ionescu nasceu de pais romênos em Värset (Vrsac, Werschetz), Banat, Iugoslávia (atualmente Sérvia) em 19 de Maio de 1943. Fez os estudos de primeiro e segundo grau na Iugoslávia, Itália e Suiça. Realizou os estudos de graduação em Compton College, University of California at Las Angeles e University of New Mexica. Ele obteve o titulo de B.S. em Quimica na University of New Mexico, Albuquerque, USA em 1964 e o título de M.S. em Quimica em 1966. Ele obteve o titulo de Ph.D. em Fisico-Quimica em $1970 \mathrm{em}$ New Mexico State University, Las Cruces, USA. Ele também cursou a Faculdade de Medicina. O Prof. Dr. L. G. Ionescu é cidadão dos Estados Unidos. Realizou estudos de pós-doutorado na University of California, Santa Barbara, USA e ocupou cargos de professor em várias universidades nos Estados Unidos e no Brasil. A sua contribuiçầo foi importante no estabelecimento de cursas à nivvel de graduação e pós-graduaçâo em química. engenharia química, farmácia, ciência e engenharia dos materiais e educaçũo em ciência no Brasil e nos Estados Unidos. As suas atividades de pesquisa incluem cintiladores liquidos, isótopos radioativos. gases nobres, termodinâmica de soluçōes, surfatantes e micelas, catálise micelar, pigmentos respiratórios, modelos de membranas e história e filosofia da ciencia. Ele preparou maís de cem pesquisadores de vírias partes do mundo, $\varepsilon$ autor de aproximadamente trezentos e cinqüenta trabalhas cientificos e foi honrado com muitos prêmios e distinçües.

KEYWORDS: History of Chemistry, History and Philosophy of Science, Noble Gases, Surfactants and Micelles, Micellar Catalysis, Solution Thermodynamics. 
We have written an extensive article in homage and tribute to Professor Dr. Lavinel G. Ionescu on the occasion of his $55^{\text {th }}$ birthday. (Cf. A.D. Martinez and B.J. Kid, South. Braz J. Chem., 6(6), 1-10, 1998).

Professor Lavinel G. Ionescu was born on May 19, 1943 in Vârset (Vrsac, Werschetz), Banat Yugoslavia (present day Serbia). His father, Gheorghe I. Ionescu, a languages teacher and linguist, was originally from Plopeni, Constanta, Romania and his mother Maria (n. Borlovanu) Ionescu, an accountant, was from Alibunar, Banat Yugoslavia.

Prof. Dr. L. G. Ionescu attended primary and secondary schools in Yugoslavia (Samianas-Barite, Alibunar and Uzdin), Italy (Trieste, Seminario Vescovile and Liceo-Ginnasio Dante Alighieri) and Switzerland (Rohrbach b.H., Bern).

He began his undergraduate studies at Compton College, Compton California in 1959 where he was awarded the Associate in Arts Degree-Cum Laude in 1961. Subsequently, he continued his undergraduate studies at the University of California, Los Angeles and the University of New Mexico, Albuquerque. He obtained the Bachelor of Science Degree with a Major in Chemistry and a Minor in Mathematics with Honors from the University of New Mexico, Albuquerque, USA, in 1964. In 1965 he became a U.S. citizen.

Prof. Dr. Lavinel G. Ionescu obtained the Master of Science Degree with a Major in Physical Organic Chemistry and a Minor in Physics from the University of New Mexico in 1966. His M.S. Thesis dealt with the use of dihydronaphthalenes and dihydrophenanthrenes as liquid scintillators, was done under the supervision of Professors Guido H. Daub and Francis Newton Hayes of the Los Alamos Scientific Laboratory and received financial support from the United States Atomic Energy Commission. 
SOUTHERN BRAZILIAN, JOURNAL OF CHEMISTRY SOUTH. BRAZ. J. CHEM., Vol. 21, No. 21, 2013

A. D. Martinez and B.J. Kid

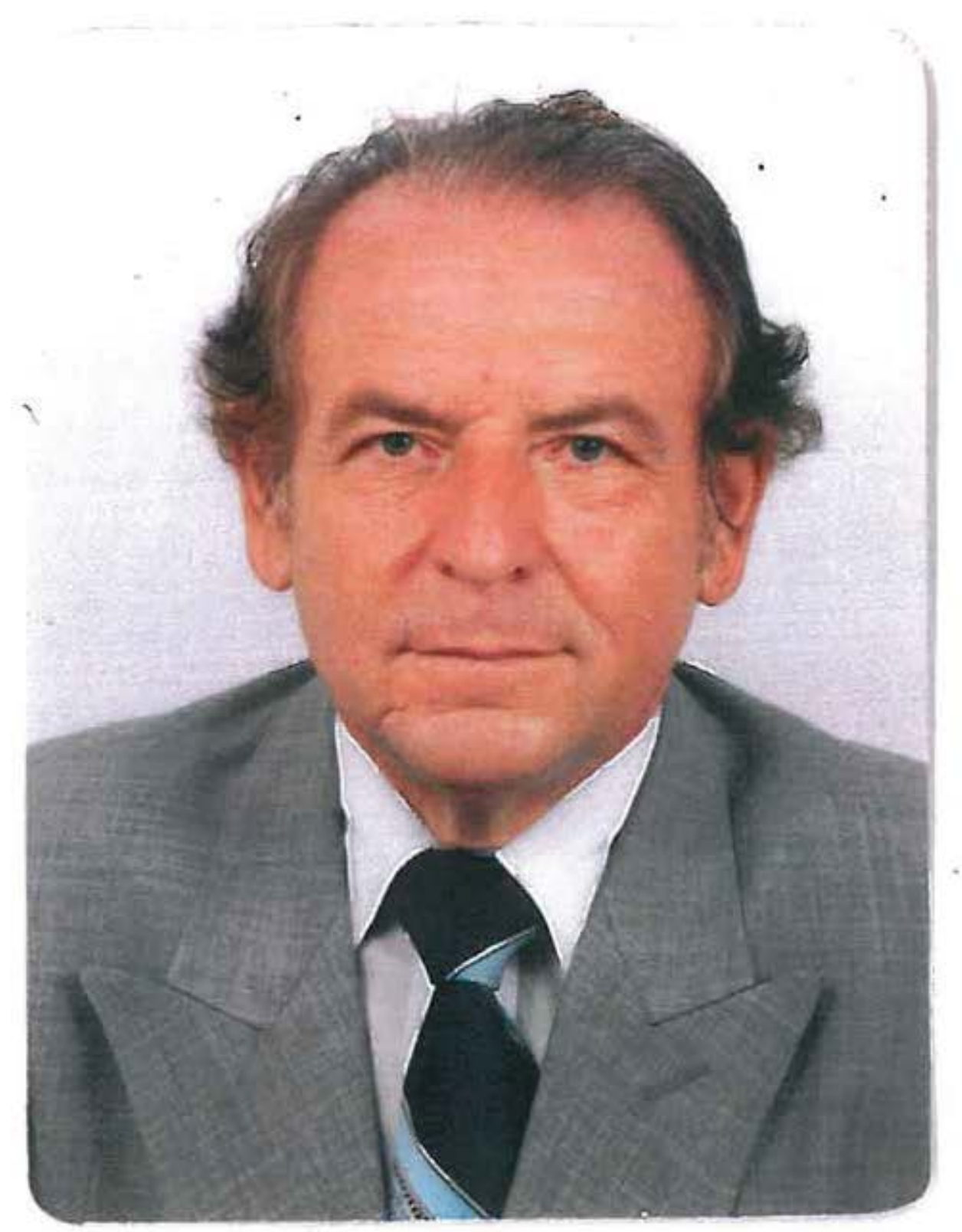

PROF. DR. LAVINEL G. IONESCU 
A Tribute to Prof. L. G. Ionescu on his $70^{\text {th }}$ Birthday

Professor L. G. Ionescu obtained the Doctor of Philosophy Degree with a Major in Physical Chemistry and Minors in Astrophysics and Biology from New Mexico State University, Las Cruces, USA in 1970. His Ph. D. Dissertation dealt mainly with solution thermodynamies, included the study of the interaction of leguminous hemoglobin with nitrogen and xenon, the properties of the xenon -water clathrate and the solubility of gases in water and aqueous solutions: The work was performed under the supervision of Professor Gordon J. Ewing and received financial support from the National Science Foundation.

Dr. L. G. Ionescu did postdoctoral work at New Mexico State University and the University of California, Santa Barbara, where he collaborated with Professor Clifford A. Bunton in the area of aggregation colloids and micellar catalysis. He also attended Medical School for several years.

Prof. Dr. Lavinel G. Ionescu began his academic career as Teaching Assistant at the University of New Mexico and New Mexico State University and as Technical Assistant at the University of Alabama, Tuscaloosa, USA, positions held from 1964 to 1970 . During the period from 1972 to 1978 he held facuity positions at New Mexico Highlands University, Las Vegas, NM, USA and the University of Detroit, Detroit, Michigan, USA.

In June of 1978, accepting an invitation from the Brazilian Ministry of Education and Culture, Dr. L. G. Ionescu went to Brazil and joined the faculty of the Universidade Federal de Santa Catarina, Florianópolis as Full Professor of Chemistry. Together with other American and foreign faculty members he helped establish the Graduate Program in Physical Chemistry and in Physises at UFSC in Florianópolis. 


\section{A. D. Martinez and B.J. Kid}

In 1983, Prof. Dr. Lavinel G. Ionescu moved to Porto Alegre where he became a facuity member at the Universidade Federal do Rio Grande do Sul. He oceupied the positions of Full Professor of Materials Science in the School of Engineering and Professor of Chemistry in the Instituto de Quimica and played an important role in the establishment of the Doctoral Program in Materials Science and Metallurgical Enginering and the Master Program in Chemistry.

In 1992, after denouncing nationwide on radio, television and newspapers ecologic erimes, embezzlement of public funds, corruption and other administrative irregularities at the Universidade Federal do Rio Grande do Sul (UFRGS) he was stripped of all his academic rights and dismissed from the faculty of UFRGS in an arbitrary act that involved harassment, political persecution and had dictatorial and inquisitional overtones. He was forced to ask for special protection from the Brazilian Federal Police and the American Consul. This shameful and sad event in the history of the Federal University of Rio Grande do Sul (UFRGS) led to legal battles that lasted more than two decades and ended up in the Brazilian Supreme Court.

Soon afterwards in 1992, Prof. Dr. Lavinel G. Ionescu was appointed Professor of Chemistry at the Universidade Luterana do Brasil (ULBRA), Canoas, RS and Pontificia Universidade Católica do Rio Grande do Sul (PUCRS), Porto Alegre, positions that he held until 2004, when he retired from academics and began to dedicate his effort to the editing of journals and scientific consulting.

He has been Visiting Professor at the University of California, Santa Barbara, Universidade de Caxias do Sul, Universidade Regional de Blumenan, Universidade Federal de Santa Maria, Insituto Luterano de Ensine Superior, Manaus, Amazonas and other universities in various continents. 
SOUTHERN BRAZILIAN JOURNAL OF CHEMISTRY

SOUTH. BRAZ. J. CHEM., Vol. 21, No. 21, 2013

A Tribute to Prof. L. G. Ionescu on His $70^{\text {th }}$ Birthday

During almost five decades as a faculty member at various universities,

Prof. Dr. L. G. Ionescu participated on a wide number of committees and held different administrative positions in the United States and Brazil.

In terms of didactic activities, Professor L. G. Ionescu taught mainly courses in physical chemistry at all levels and occasionally general and inorganic chemistry, biochemistry, quantum mechanies and history and philosophy of science.

He was the first scientist in Brazil to teach a formal advanced course on matter and materials under extreme conditions in Porto Alegre and Manaus, Amazonas.

Prof. Dr. L. G. Ionescu's research activities include liquid scintillators, radioactive isotopes of $\mathrm{Fe}$ and $\mathrm{Th}$, noble gases, solution thermodynamics, surfactants and micelles, micellar catalysis, respiratory pigments, membrane models and history and philosophy of science. He has trained more than one hundred scientists from different parts of the world and is the author of approximately 350 scientific papers. A list of representative publications is given at the end of this article.

Prof. Dr. L. G. Ionescu is fuent in many European languages, including Romanian, Serbo-Croatian, Italian, French, Spanish, Portuguese, German, English and others. At times, he surprises people conversing in Chinese, Japanese, Swahili or Hindi.

Prof. L. G. Ionescu is a widely traveled person and his journeys included the Aretic Circle, Sonoran Desert, Sierra Madre, Carpathians, Alps, the Andes and Aconcagua, the Islands of the Pacific and the Amazon.

His hobbies include stamp collecting, mountain climbing, swimming, astronomy, folklore and the traditions of many people. 
SOUTHERN BRAZILIAN JOURNAL OF CHEMISTRY

SOUTH. BRAZ. J. CHEM., Vol. 21, No. 21, 2013

\section{A. D. Martinez and B. J. Kid}

Prof. Dr, L. G. Ionescu became widely known throughout Brazil as Leader of the Pró-Ecologia Group of Porto Alegre and Viamão after denouncing the ecologic crimes of the Campus do Vale of the Federal University of Rio Grande do Sul, widespread corruption and embezzlement of public funds at the same institution. He appeared on all television channels and many radio programs throughout Brazil and his interviews covered entire pages of Jornal do Brasil, the country's most important newspaper at the time.

On the streets of Porto Alegre, many people greet him as the "Courageous Professor" and in Viamão, city where he lives since 1983, people address him respectfully as Professor or Professor Lavinel. Dr. Dimitrios Samios, former Dean of the College of Chemistry and UFRGS's best known chemist, has made public depositions considering Prof. D. L. G. Ionescu an archetype, a model person or prototype that appeared at the wrong place before his time.

Prof. Dr. Lavinel G. Ionescu has received many prizes, distinctions and awards, has given invited lectures in more than twenty five countries and organized or helped organize many scientific events all over the world.

We cite only the Symposium on Chemistry in Latin America during the First Chemical Congress of the North American Continent in Mexico City in 1975 and various International Symposia on Surfactants in Solution.

He is a member of the American Chemical Society since 1965, Sigma XiScientific Research Society of America, Sigma Pi Sigma-National Physics Honor Society (USA), New Mexico Academy of Science, Michigan Academy of Arts, Science and Letters, New York Academy of Sciences, Founding Member of the American Romanian Academy of Arts and Sciences together with 


\title{
SOUTHERN BRAZILIAN, JOURNAL OF CHEMISTRY SOUTH. BRAZ. J. CHEM., Vol. 21, No. 21, 2013
}

\author{
A Tribute to Prof. L. G. Ionescu on His $70^{k}$ Birthday
}

Mons. O. Bârlea, Mircea Eliade and George Emil Palade; and Founding President of Sarmisegetusa Research Group of Santa Fe, New Mexico, USA and member of many other learned societies, including the Astronomical Society of Las Cruces.

He was Researcher $L A$ of the Brazilian National Research Council (CNPq) and in 2004 he received the Technology Prize from PETROBRAS (Brazilian Petroleum Company).

Prof. Dr. L. G. Ionescu is an Honorary Citizen of the State of New Mexico and was Brazilian National Representative at the International Union of Pure and Applied Chemistry (IUPAC).

When asked about his main contributions in teaching, Prof. L. G. Ionescu cites many courses in Quantum Chemistry that opened the frontier in Southern Brazil, the course on Matter and Materials under Extreme Conditions and the course on History and Philosophy of Science, given to thousands of freshmen students in the sciences and mathematies at ULBRA.

In research he mentions especially the work on relaxation phenomena and liquid dynamics, the use of micelle formation to probe the structure of water and various studies in solution thermodynamics.

He also likes to stress his contributions for several decades, especially as Chief Editor of the Southern Brazilian Journal of Chemistry and Editor of the Brazilian Journal of Materials Science and Engineering.

We salute Professor Dr. Lavinel G. Ionescu on the occasion of his seventieth birthday, congratulate him for his effort and contributions for almost half a century and wish him happiness, good health, good will and success for the days to come.

The SOUTHERN BRAZILIAN JOURNAL OF CHEMISTRY (ISSN: 2674-6891; 0104-5431) is an open-access journal since 1993. Journal DOI: 10.48141/SBJCHEM. http://www.sbjchem.com.

This text was introduced in this file in 2021 for compliance reasons.

(C) The Author(s)

OPEN ACCESS. This article is licensed under a Creative Commons Attribution 4.0 (CC BY 4.0) International License, which permits use, sharing , adaptation , distribution , and reproduction in any medium or format, as long as you give appropriate credit to the original author(s) and the source, provide a link to the Creative

Commons license, and indicate if changes were made. The images or other third-party material in this article are included in the article's Creative Commons license unless indicated otherwise in a credit line to the material. If material is not included in the article's Creative Commons license and your intended use is not permitted by unless indicated otherwise in a credit line to the material. If material is not included in the article's Creative Commons license and your intended use is not permitted by
statutory regulation or exceeds the permitted use, you will need to obtain permission directly from the copyright holder. To view a copy of this license , visit http:// creativecommons.org/licenses/by/4.0/. 